\title{
Prevalence of Haemarthrosis and Clinical Impact on The Musculoskeletal System in People With Haemophilia in The United Kingdom; Evaluation of UK National Haemophilia Database and Haemtrack Patient Reported Data.
}

Richard Wilkins ( $\square$ r.a.wilkins@leeds.ac.uk)

Leeds Institute of Rheumatic and Musculoskeletal Medicine (LIRMM), University of Leeds,

\section{David Stephensen}

The Royal London Hospital Haemophilia Centre, Barts and The London School of Medicine and

Dentistry, Queen Mary University London, London

Heidi Siddle

Leeds Institute of Rheumatic and Musculoskeletal Medicine (LIRMM), University of Leeds,

\section{Martin Scott}

University Department of Clinical Haematology, Manchester Royal Infirmary, Manchester

\section{Hua Xiang}

UKHCDO National Haemophilia Database, Manchester

\section{Elizabeth Horn}

Leeds haemophilia Comprehensive Care Centre, Leeds Teaching Hospitals NHS trust, Leeds

\section{Ben Palmer}

UKHCDO National Haemophilia Database, Manchester

\section{Graham Chapman}

School of Sport and Health Sciences, University of Central Lancashire, Preston

\section{Michael Richards}

Leeds haemophilia Comprehensive Care Centre, Leeds Teaching Hospitals NHS trust, Leeds

\section{Rebecca Walwyn}

Clinical Trials Research Unit, Leeds Institute of Clinical Trials Research, University of Leeds, Leeds, UK

\section{Anthony Redmond}

Leeds Institute of Rheumatic and Musculoskeletal Medicine (LIRMM), University of Leeds,

\section{Research Article}

Keywords: Prevalence, haemarthrosis, haemarthropathy, annualised joint bleed rate, haemophilia joint health score, prophylaxis 
Posted Date: December 2nd, 2020

DOl: https://doi.org/10.21203/rs.3.rs-111806/v1

License: (c) (i) This work is licensed under a Creative Commons Attribution 4.0 International License. Read Full License

Version of Record: A version of this preprint was published at BMJ Open on January 13th, 2022. See the published version at https://doi.org/10.1136/bmjopen-2021-052358. 


\section{Abstract}

Introduction; Severe haemophilia is a rare $x$-linked recessive genetic disorder characterised by bleeding into soft tissue and joints. Haemarthrosis is the most common bleeding manifestation in haemophilia, leading to haemarthropathy. The ankle joint has been reported as the most common site of bleeding, but it is unclear whether the ankle is most affected in terms of joint health status.

Aims; To determine the prevalence of joint bleeding and musculoskeletal health status at an individual joint level of children and adults with severe haemophilia A and B without a current inhibitor.

Methods; Application was made to the National Haemophilia Database (NHD) with a request for the following; Haemtrack patient reported treatment record and Haemophilia Joint Health Scores (HJHS) in children ( $<18 \mathrm{y})$ and adults ( $\geq 18 \mathrm{y})$ with severe haemophilia $A(H A)$ and $B(H B)(F V I I I / F I X,<0.01 \mathrm{iu} / \mathrm{ml})$ without a current inhibitor. Data were collated and reported for 1st January to 31st December 2018.

Results; 2238 cases were identified, of which 273 were Haemtrack compliant with contemporaneous HJHS. The median (IQR) age of children was 10 (6-13) and adults 40 (29-50) years. Haemarthrosis prevalence in $\mathrm{HA} / \mathrm{HB}$ children was $33 \%$ and $47 \%$, respectively and $60 \%$ and $42 \%$, respectively, in adults. The most common haemarthrosis site in children was the knee in HA and ankle in HB. In adults, the incidence of haemarthrosis at the ankles and elbows was equal. Median (IQR) total HJHS in HA/HB children were $0(0 ; 0)$. In adults with HA/HB, HJHS were $18(6 ; 31)$ and $11(5 ; 24)$, respectively. In adults with $\mathrm{HA} / \mathrm{HB}$, mean (SD) ankle HJHS of $3.8(4.1)$ and median $4.0(0.0 ; 8.0)$ were higher than the knee (mean $2.9(4.1)$ and median $1.0(0.0 ; 5.0)$ and elbow (mean $3.3(4.1)$ and median $1.0(0.0 ; 7.0)$ joints.

Conclusion; During 2018, NHD prevalence data of haemarthrosis indicate only two-thirds of children and one-third of adults from a UK cohort compliant with prophylaxis were bleed free. HJHS of zero in children suggests joint health status is either unaffected during childhood or undetected by HJHS. In adults, higher HJHS are reported for the ankles indicating worse joint health.

\section{Introduction}

Haemophilia is a rare $\mathrm{x}$-linked recessive genetic disorder characterised by bleeding into soft tissue and joints [1]. The most common forms are haemophilia $A$ and $B$ affecting 1:10000 and 1:30000 respectively. The disease is further characterised by the levels of factor VIII (FVIII) and factor VIX (FVIX), with the most severely affected having less than $1 \%(<0.01 \mathrm{IU} / \mathrm{mL})$ circulating clotting factor (severe haemophilia) [2]. Musculoskeletal bleeding is the most common haemorrhagic manifestation, with $90 \%$ of bleeds occurring in muscles or joints [1]. The presence of blood products within the joint space and the process of removal leads to synovial hypertrophy, haemosiderin deposition and eventually arthropathic joint changes [3]. Over time, repeated haemarthrosis results in chronic synovitis, changes in cartilage and bone composition and progressive chronic haemarthropathy $[4,5]$. 
Infusion of replacement clotting factor concentrates (CFC) is prescribed with the aim of elevating circulating factor to a level that halts spontaneous and traumatic bleeding [1]. CFC treatment is not without complication. The development of anti-Factor antibodies or inhibitors produces an immune response to CFC infusion significantly reduces the effectiveness of CFC treatment. Development of inhibitors increase the risk of bleeding, joint damage and requirement for factor treatment bypassing agents [6]. Ultimately the aim of modern treatment of haemophilia is prevention of joint bleeds with a target of achieving zero bleeds whenever possible. Prevention of haemarthrosis in all age groups is important and in particular in children, where musculoskeletal immaturity exposes joints to greater risk of damage in later life. Multiple studies have shown that early initiation of CFC prophylaxis in children delays joint damage and reduces joint disease [7-10]. In adults, multi-joint haemarthropathy remains a common feature of the disease, but even prophylaxis started in adulthood decreases bleeding, improves pain and improves health related QoL (HRQoL) [11]. Therefore in children and adults prophylaxis is considered the standard of care for all patients $[11,12]$. Traditionally, prophylactic treatment in severe haemophilia aims to maintain factor VIII (FVIII) or Factor IX (FIX) at a trough level $>0.01 \mathrm{iu} / \mathrm{ml}$. It is apparent that many patients experience spontaneous as well as traumatic bleeds, despite achieving trough factor levels $>0.01 \mathrm{iu} / \mathrm{ml}$. Several approaches have been adopted or are being investigated with the aim of attaining complete bleed avoidance, including more individualised treatment with standard half-life products, the use of coagulation factors with extended half-lives, and innovative non-factor treatments [12-15].

Recent evaluation of real world treatment regimes in severe and moderate haemophilia in the UK and Europe, has shown that despite adequate coagulation factor concentrate availability, treatment is still suboptimal. In 2015, data from the United Kingdom National Haemophilia Database (NHD) reported median (IQR) annualised bleed rates (ABR)/ annualised joint bleed rates (AJBR) in children (0-11y) and adolescents (12-18y) of 1.0 (0.0-0.5)/ 0.0 (0.0-1.0) and 2.0 (0.0-7.0)/ 1.0 (0.0-3.0), respectively. ABR in adults with severe haemophilia A on prophylaxis were 2.0 (IQR 0.0-7.0) and AJBR was 1.0 (IQR 0.0-4.0) with only $29 \%$ bleed free and $34 \%$ joint bleed free [16]. Similarly, reported European (Belgium, France, Germany, Italy, Spain, Sweden, and UK) data shows median AJBR of 1.0 - 4.0. [16, 17]. However, data on bleeding frequency and severity of haemarthropathy at an individual joint level is lacking.

The main sites of haemarthrosis are the elbows, ankles and the knees, with the shoulders, wrists and hips less common and not collated by the NHD or recorded as part of the HJHS [18]. With increased uptake of prophylaxis and new emerging treatments, the distribution of haemarthrosis, incidence at each joint and joint health status are of interest but are unknown. The aim of this study is to establish the current prevalence and distribution of haemarthrosis in order to provide a snapshot of bleed rates and joint health status of UK patients with severe haemophilia A and B without inhibitors. Understanding the distribution and prevalence of haemarthrosis and joint health in children and adults who are compliant with prophylaxis may provide direction for future pharmacological research and targeted interventions, including non-pharmacological interventions and intra-articular therapies commonly used in the management of MSK conditions. 


\section{Study aims}

The aims of this study were to determine the prevalence and incidence of joint bleeding and the musculoskeletal health status at an individual joint level in children and adults with severe haemophilia $A$ and $B$ without a current inhibitor.

\section{Methods}

Ethical approval was obtained on $24^{\text {th }}$ January 2017 (IRAS: 206141, R\&D: PD16/227) Approval to access data from the UKHCDO NHD Data Analysis Group was granted on $12^{\text {th }}$ July 2019 and the analysis report produced on the $4^{\text {th }}$ October 2019 . The study has been reported in accordance with the UKHCDO NHD guidelines and regulations.

Data on bleed prevalence and site were collated retrospectively from Haemtrack and Haemophilia Joint Health Scores from the National Haemophilia Database. Haemtrack is a UK national online treatment diary whereby individual patients regularly report details of treatments with coagulation factor concentrates (CFC) $[19,20]$. Details of home delivery of CFC treatment to patients is recorded by the corresponding haemophilia treatment centre and then uploaded to the NHD. When CFC is administered by the patient that individual treatment is then recorded on Haemtrack, including the reason for each treatment such as prophylaxis or bleed treatment and the site of each bleed. Data recorded in Haemtrack are then integrated with NHD [20]. The 2018-2019 UKHCDO report indicated median compliance at haemophilia comprehensive care centres (CCC) and haemophilia treatment centres ( $\mathrm{HC}$ ) of $90 \%$ and $93 \%$ respectively [21]. The HJHS is a measure of joint health status in patients with haemophilia and form part of the UKHCDO haemophilia management guidelines [22, 23]. The HJHS Version 2.1 is collated as six individual joint scores (0-20) and compiled with a global gait score (0-4) to a total score (0-124). A higher HJHS score represents worse joint health.

Participants were children ( $<18$ years old) and adults ( $\geq 18$ years old) with severe haemophilia $A$ and $B$ (FVIII or FIX $<0.01 \mathrm{IU} / \mathrm{mL}$ ) without a current inhibitor, who had been issued with coagulation factor concentrates in the UK between $1^{\text {st }}$ January and $31^{\text {st }}$ December 2018. Regular prophylaxis was defined for those using standard half-life (SHL) prophylaxis as $>=2$ infusions per week for Haemophilia $A$, and $>=1$ infusions/week for haemophilia $B$ for $>45$ weeks/year; for patients using extended half-life (EHL) products, $>=1$ infusions/week for haemophilia A, and more than once every two weeks for haemophilia $B$ for $>45$ weeks/year. Those included in the analysis were Haemtrack compliant (defined as recorded use of $\geq 75 \%$ of received factor concentrate) with a corresponding electronically recorded Haemophilia Joint Health Score (HJHS) Version 2.1.

The joint bleed prevalence (\%) for paediatric and adult patients and AJBR and HJHS were collated from Haemtrack and NHD. AJBR were reported by patients through the Haemtrack and recorded over the 12month study period ( $1^{\text {st }}$ January to $31^{\text {st }}$ December 2018). Only data from the most compliant patients ( $\geq 75 \%$ received factor concentrate vs recorded in Haemtrack) were reported as per the NHD threshold for 
data analysis and reporting. Joint bleed prevalence, AJBR and HJHS are reported for all joints (total) and in each individual joint. Data are summarised using means and standard deviations (SD) or medians and interquartile ranges (IQR, 25; 75 percentiles).

\section{Results}

During 2018, 2238 individuals with severe haemophilia $A(n=1889)$ and $B(n=349)$ without a current inhibitor were registered with the NHD and 1396 were registered with Haemtrack. Contemporaneous Haemtrack and electronically recorded fully itemised HJHS data were available for 273 individuals, of which $86.8 \%(n=237)$ had haemophilia A and 36 haemophilia B. Participant age and treatment characteristics are presented in Table 1. Ninety-six per cent of patients with haemophilia $A$ and all with haemophilia B in the cohort were adherent to prophylaxis.

\section{Table 1: Participant characteristics}

\begin{tabular}{|c|c|c|c|c|}
\hline \multirow{2}{*}{$\begin{array}{l}\text { Patient } \\
\text { characteristics }\end{array}$} & \multicolumn{2}{|c|}{ Haemophilia A } & \multicolumn{2}{|c|}{ Haemophilia B } \\
\hline & $\begin{array}{l}\text { Age }<18 \\
(n=80)\end{array}$ & $\begin{array}{l}\text { Age } \geq 18 \\
(n=157)\end{array}$ & $\begin{array}{l}\text { Age }<18 \\
(n=17)\end{array}$ & Age $\geq 18(n=19)$ \\
\hline Age (median, IQR) & $10(7 ; 13)$ & $40(29 ; 50)$ & $12(7 ; 14)$ & $45(25 ; 48)$ \\
\hline SHL & $67 \%(n=54)$ & $77 \%(n=121)$ & $18 \%(n=3)$ & $32 \%(n=6)$ \\
\hline EHL & $29 \%(n=23)$ & $23 \%(n=36)$ & $70 \%(n=12)$ & $42 \%(n=8)$ \\
\hline SHL-EHL & $4 \%(n=3)$ & $0 \%$ & $12 \%(n=2)$ & $26 \%(n=5)$ \\
\hline
\end{tabular}

SHL= Standard Half-life product, EHL= Extended Half-life product, SHL-EHL=switch from a SHL to a EHL during the 12 month study period.

\section{Joint bleed prevalence and annualised bleed rate}

Joint bleed prevalence and individual joint bleed incidence are categorised by age, haemophilia type and joint, and are presented in Table 2. Children with haemophilia A (32.5\%) and haemophilia B (47.1\%) reported at least one incidence of joint bleeding. Adults with haemophilia A (59.9\%) and B (42.1\%) reported at least one bleed over the same time period. Mean AJBR by ankles, knees, and elbows are presented in Figure 1.

Table 2. Annual joint bleed prevalence and AJBR of children and adults 


\begin{tabular}{|c|c|c|c|c|c|c|}
\hline \multirow{2}{*}{\multicolumn{2}{|c|}{$\begin{array}{l}\text { Annual Joint Bleeds } \\
\text { Joint }\end{array}$}} & & \multicolumn{2}{|c|}{ Haemophilia A } & \multicolumn{2}{|c|}{ Haemophilia B } \\
\hline & & & $\begin{array}{l}\text { Age }<18 \\
(n=80)\end{array}$ & $\begin{array}{l}\text { Age } \geq 18 \\
(n=157)\end{array}$ & $\begin{array}{l}\text { Age }<18 \\
(n=17)\end{array}$ & $\begin{array}{l}\text { Age } \geq 18 \\
(n=19)\end{array}$ \\
\hline \multirow[t]{3}{*}{$\begin{array}{l}\text { All } \\
\text { Joints }\end{array}$} & $\begin{array}{l}\text { Joint bleed } \\
\text { prevalence }\end{array}$ & n (\%) & $26(32.5)$ & $94(59.9)$ & $8(47.1)$ & $8(42.1)$ \\
\hline & $\begin{array}{l}\text { Annual joint } \\
\text { bleed Rate }\end{array}$ & $\begin{array}{l}\text { Mean } \\
\text { (SD) }\end{array}$ & $0.81(1.68)$ & $3.90(7.00)$ & $1.00(1.18)$ & $2.04(3.59)$ \\
\hline & & $\begin{array}{l}\text { Median } \\
\text { (IQR) }\end{array}$ & $\begin{array}{l}0.0 \\
(0.0 ; 1.0)\end{array}$ & $1.0(0.0 ; 4.4)$ & $\begin{array}{l}0.0 \\
(0.0 ; 2.0)\end{array}$ & $0.0(0.0 ; 3.5)$ \\
\hline \multirow[t]{3}{*}{$\begin{array}{l}\text { Right } \\
\text { Ankle }\end{array}$} & $\begin{array}{l}\text { Joint bleed } \\
\text { prevalence }\end{array}$ & n (\%) & $2(2.5)$ & $27(17.2)$ & $1(5.9)$ & $2(10.5)$ \\
\hline & $\begin{array}{l}\text { Annual joint } \\
\text { bleed Rate }\end{array}$ & $\begin{array}{l}\text { Mean } \\
\text { (SD) }\end{array}$ & $0.08(0.57)$ & $0.38(1.06)$ & $0.06(0.24)$ & $0.16(0.51)$ \\
\hline & & $\begin{array}{l}\text { Median } \\
\text { (IQR) }\end{array}$ & $\begin{array}{l}0.0 \\
(0.0 ; 0.0)\end{array}$ & $0.0(0.0 ; 0.0)$ & $\begin{array}{l}0.0 \\
(0.0 ; 0.0)\end{array}$ & $0.0(0.0 ; 0.0)$ \\
\hline \multirow[t]{3}{*}{$\begin{array}{l}\text { Left } \\
\text { ankle }\end{array}$} & $\begin{array}{l}\text { Joint bleed } \\
\text { prevalence }\end{array}$ & n (\%) & $5(6.3)$ & $35(22.3)$ & $5(29.4)$ & $2(10.5)$ \\
\hline & $\begin{array}{l}\text { Annual joint } \\
\text { bleed Rate }\end{array}$ & $\begin{array}{l}\text { Mean } \\
\text { (SD) }\end{array}$ & $0.10(0.44)$ & $0.61(1.98)$ & $0.36(0.62)$ & $0.11(0.33)$ \\
\hline & & $\begin{array}{l}\text { Median } \\
\text { (IQR) }\end{array}$ & $\begin{array}{l}0.0 \\
(0.0 ; 0.0)\end{array}$ & $0.0(0.0 ; 0.0)$ & $\begin{array}{l}0.0 \\
(0.0 ; 1.0)\end{array}$ & $0.0(0.0 ; 0.0)$ \\
\hline \multirow[t]{3}{*}{$\begin{array}{l}\text { Right } \\
\text { knee }\end{array}$} & $\begin{array}{l}\text { Joint bleed } \\
\text { prevalence }\end{array}$ & $\mathrm{n}(\%)$ & 13 (16.3) & $27(17.2)$ & $1(5.9)$ & $2(10.5)$ \\
\hline & $\begin{array}{l}\text { Annual joint } \\
\text { bleed Rate }\end{array}$ & $\begin{array}{l}\text { Mean } \\
\text { (SD) }\end{array}$ & $0.20(0.56)$ & $0.41(1.48)$ & $0.18(0.73)$ & $0.53(2.08)$ \\
\hline & & $\begin{array}{l}\text { Median } \\
\text { (IQR) }\end{array}$ & $\begin{array}{l}0.0 \\
(0.0 ; 0.0)\end{array}$ & $0.0(0.0 ; 0.0)$ & $\begin{array}{l}0.0 \\
(0.0 ; 0.0)\end{array}$ & $0.0(0.0 ; 0.0)$ \\
\hline \multirow[t]{3}{*}{$\begin{array}{l}\text { Left } \\
\text { knee }\end{array}$} & $\begin{array}{l}\text { Joint bleed } \\
\text { prevalence }\end{array}$ & n (\%) & $7(8.8)$ & $24(15.3)$ & $1(5.9)$ & $2(10.5)$ \\
\hline & $\begin{array}{l}\text { Annual joint } \\
\text { bleed Rate }\end{array}$ & $\begin{array}{l}\text { Mean } \\
\text { (SD) }\end{array}$ & $0.11(0.39)$ & $0.29(0.96)$ & $0.10(0.42)$ & $0.21(0.72)$ \\
\hline & & $\begin{array}{l}\text { Median } \\
\text { (IQR) }\end{array}$ & $\begin{array}{l}0.0 \\
(0.0 ; 0.0)\end{array}$ & $0.0(0.0 ; 0.0)$ & $\begin{array}{l}0.0 \\
(0.0 ; 0.0)\end{array}$ & $0.0(0.0 ; 0.0)$ \\
\hline \multirow[t]{3}{*}{$\begin{array}{l}\text { Right } \\
\text { elbow }\end{array}$} & $\begin{array}{l}\text { Joint bleed } \\
\text { prevalence }\end{array}$ & n (\%) & $6(8.0)$ & $29(18.5)$ & $1(5.9)$ & $3(15.8)$ \\
\hline & $\begin{array}{l}\text { Annual joint } \\
\text { bleed Rate }\end{array}$ & $\begin{array}{l}\text { Mean } \\
\text { (SD) }\end{array}$ & $0.08(0.27)$ & $0.39(1.12)$ & $0.06(0.24)$ & $0.28(0.78)$ \\
\hline & & $\begin{array}{l}\text { Median } \\
\text { (IQR) }\end{array}$ & $\begin{array}{l}0.0 \\
(0.0 ; 0.0)\end{array}$ & $0.0(0.0 ; 0.0)$ & $\begin{array}{l}0.0 \\
(0.0 ; 0.0)\end{array}$ & $0.0(0.0 ; 0.0)$ \\
\hline
\end{tabular}




\begin{tabular}{|c|c|c|c|c|c|c|}
\hline \multirow[t]{3}{*}{$\begin{array}{l}\text { Left } \\
\text { elbow }\end{array}$} & $\begin{array}{l}\text { Joint bleed } \\
\text { prevalence }\end{array}$ & $\mathrm{n}(\%)$ & $4(5.0)$ & 35 (22.3) & $1(5.9)$ & $2(10.5)$ \\
\hline & \multirow[t]{2}{*}{$\begin{array}{l}\text { Annual joint } \\
\text { bleed Rate }\end{array}$} & $\begin{array}{l}\text { Mean } \\
\text { (SD) }\end{array}$ & $0.12(0.73)$ & $0.81(2.38)$ & $0.06(0.24)$ & $0.17(0.53)$ \\
\hline & & $\begin{array}{l}\text { Median } \\
\text { (IQR) }\end{array}$ & $\begin{array}{l}0.0 \\
(0.0 ; 0.0)\end{array}$ & $0.0(0.0 ; 0.0)$ & $\begin{array}{l}0.0 \\
(0.0 ; 0.0)\end{array}$ & $0.0(0.0 ; 0.0)$ \\
\hline
\end{tabular}

Joint bleed prevalence (\%): Numerator $=$ number of patients who had bleeds, Denominator $=$ total cohort number,

\section{Haemophilia joint health score}

HJHS categorised by age, haemophilia type and joint are presented in Table 3. Median (IQR) of HJHS in children were $0.0(0.0 ; 0.0)$ in both haemophilia A and B. In adults the total HJHS were higher than in children; the total HJHS is higher in haemophilia A than haemophilia B. At an individual joint level both mean (SD) and median (IQR) ankle HJHS of $4.6(4.3) / 4.0(0.0 ; 8.0)$ were higher than for the knee 2.9 $(4.1) / 1.00(0.0 ; 5.0)$ and elbow $3.3(4.1) / 1.0(0.0 ; 7.0)$.

Table 3. Haemophilia joint health scores for children and adults 


\begin{tabular}{|c|c|c|c|c|c|c|}
\hline \multirow{2}{*}{\multicolumn{3}{|c|}{$\begin{array}{l}\text { Haemophilia joint health scores } \\
\text { Joint }\end{array}$}} & \multicolumn{2}{|c|}{ Haemophilia A } & \multicolumn{2}{|c|}{ Haemophilia B } \\
\hline & & & \multirow{2}{*}{$\begin{array}{l}\text { Age < 18 } \\
(n=80)\end{array}$} & \multirow{2}{*}{$\begin{array}{l}\begin{array}{l}\text { Age } \geq 18 \\
(n=157)\end{array} \\
21.2(16.8)\end{array}$} & \multirow{2}{*}{$\begin{array}{l}\begin{array}{l}\text { Age }<18 \\
(n=17)\end{array} \\
0.4(0.9)\end{array}$} & \multirow{2}{*}{$\begin{array}{l}\begin{array}{l}\text { Age } \geq 18 \\
(n=19)\end{array} \\
15.4(15.1)\end{array}$} \\
\hline $\begin{array}{l}\text { All } \\
\text { Joints }\end{array}$ & $\begin{array}{l}\text { HJHS } \\
\text { (total) }\end{array}$ & $\begin{array}{l}\text { Mean } \\
\text { (SD) }\end{array}$ & & & & \\
\hline & & $\begin{array}{l}\text { Median } \\
\text { (IQR) }\end{array}$ & $0.0(0.0 ; 0.0)$ & $\begin{array}{l}18.0 \\
(6.0 ; 31.0)\end{array}$ & $0.0(0.0 ; 0.0)$ & $\begin{array}{l}11.0 \\
(5.0 ; 24.0)\end{array}$ \\
\hline \multirow[t]{2}{*}{$\begin{array}{l}\text { Right } \\
\text { Ankle }\end{array}$} & $\begin{array}{l}\text { HJHS } \\
\text { (total) }\end{array}$ & $\begin{array}{l}\text { Mean } \\
\text { (SD) }\end{array}$ & $0.1(0.4)$ & $4.6(4.2)$ & $0.0(0.0)$ & $3.6(4.1)$ \\
\hline & & $\begin{array}{l}\text { Median } \\
\text { (IQR) }\end{array}$ & $0.0(0.0 ; 0.0)$ & $4.0(0.0 ; 8.0)$ & $0.0(0.0 ; 0.0)$ & $2.0(0.0 ; 7.0)$ \\
\hline \multirow[t]{2}{*}{$\begin{array}{l}\text { Left } \\
\text { ankle }\end{array}$} & $\begin{array}{l}\text { HJHS } \\
\text { (total) }\end{array}$ & $\begin{array}{l}\text { Mean } \\
\text { (SD) }\end{array}$ & $0.0(0.1)$ & $4.6(4.3)$ & $0.3(0.8)$ & $4.8(4.1)$ \\
\hline & & $\begin{array}{l}\text { Median } \\
\text { (IQR) }\end{array}$ & $0.0(0.0 ; 0.0)$ & $4.0(0.0 ; 8.0)$ & $0.0(0.0 ; 0.0)$ & $4.0(1.0 ; 8.0)$ \\
\hline \multirow[t]{2}{*}{$\begin{array}{l}\text { Right } \\
\text { knee }\end{array}$} & $\begin{array}{l}\text { HJHS } \\
\text { (total) }\end{array}$ & $\begin{array}{l}\text { Mean } \\
\text { (SD) }\end{array}$ & $0.2(0.5)$ & $2.7(3.9)$ & $0.0(0.0)$ & $2.5(4.6)$ \\
\hline & & $\begin{array}{l}\text { Median } \\
\text { (IQR) }\end{array}$ & $0.0(0.0 ; 0.0)$ & $1.0(0.0 ; 4.0)$ & $0.0(0.0 ; 0.0)$ & $0.0(0.0 ; 1.0)$ \\
\hline \multirow[t]{2}{*}{$\begin{array}{l}\text { Left } \\
\text { knee }\end{array}$} & $\begin{array}{l}\text { HJHS } \\
\text { (total) }\end{array}$ & $\begin{array}{l}\text { Mean } \\
\text { (SD) }\end{array}$ & $0.1(0.3)$ & $2.9(4.1)$ & $0.1(0.2)$ & $1.3(2.2)$ \\
\hline & & $\begin{array}{l}\text { Median } \\
\text { (IQR) }\end{array}$ & $0.0(0.0 ; 0.0)$ & $1.00(0.0 ; 5.0)$ & $0.0(0.0 ; 0.0)$ & $0.0(0.0 ; 2.0)$ \\
\hline \multirow[t]{2}{*}{$\begin{array}{l}\text { Right } \\
\text { elbow }\end{array}$} & $\begin{array}{l}\text { HJHS } \\
\text { (total) }\end{array}$ & $\begin{array}{l}\text { Mean } \\
\text { (SD) }\end{array}$ & $0.1(0.7)$ & $3.3(4.1)$ & $0.0(0.0)$ & $1.3(2.6)$ \\
\hline & & $\begin{array}{l}\text { Median } \\
\text { (IQR) }\end{array}$ & $0.0(0.0 ; 0.0)$ & $1.0(0.0 ; 7.0)$ & $0.0(0.0 ; 0.0)$ & $0.0(0.0 ; 1.0)$ \\
\hline \multirow[t]{2}{*}{$\begin{array}{l}\text { Left } \\
\text { elbow }\end{array}$} & $\begin{array}{l}\text { HJHS } \\
\text { (total) }\end{array}$ & $\begin{array}{l}\text { Mean } \\
\text { (SD) }\end{array}$ & $0.2(1.2)$ & $3.2(4.2)$ & $0.1(0.2)$ & $2.1(4.0)$ \\
\hline & & $\begin{array}{l}\text { Median } \\
\text { (IQR) }\end{array}$ & $0.0(0.0 ; 0.0)$ & $1.0(0.0 ; 6.0)$ & $0.0(0.0 ; 0.0)$ & $0.0(0.0 ; 1.0)$ \\
\hline
\end{tabular}

HJHS: Global Gait score not included

\section{Discussion}

In this study we report the current prevalence of haemarthrosis in children and adults with severe haemophilia without current inhibitors, and associated HJHS as a measure of joint status. The study was conducted retrospectively, using data from 2018. In a national cohort of 2338 individuals, 273 fulfilled 
criteria for compliant Haemtrack reporting and had contemporaneous, electronically-recorded, fully itemised HJHS data.

In children with severe haemophilia, average AJBR were low across haemophilia types. However, one in three children experienced a joint bleed during the 12-month data collection period. The majority of those included would have typically been provided prophylaxis from an early age and continue to adhere to a prophylaxis regime, but $30 \%$ of children still experienced haemarthrosis during the 12 month data collection period. HJHS itemised by joint were very low in children (Table 3) suggesting either minimal haemarthropathy or that the HJHS might not be sensitive to early joint changes following haemarthrosis. Canine, mouse and human in-vitro models have demonstrated chondrocyte apoptosis and reduced proteoglycan synthesis affecting cartilage matrix turnover within 48-96 hours of an induced joint bleed, suggesting a single joint bleed may have detrimental effects on joint cartilage [24-26]. Formally reported bleed rates in the NHD are relatively low, however micro bleeding, or subclinical bleeding not clinically detectable, or experienced by the patient is an emerging theme in haemophilia. Incidences of subclinical bleeding may be attributed to the deterioration of joint health despite no clinically detectable signs of a joint bleed [3].

In the adult population, AJBR were higher than those reported in children, with mean (SD) AJBR of 3.9 (7.0) and median (IQR) 1.0 (0.0-4.4) in haemophilia A and 2.0 (3.6) and 0.0 (0.0-3.5) in haemophilia B, respectively. The prevalence was also higher with $60 \%$ and $41 \%$ of adults with haemophilia $A$ and $B$, respectively, experiencing a minimum of one haemarthrosis over the 12-month period. HJHS scores at the ankle joint were similar to the elbows followed by the knee. Interestingly the median scores at both the knee and elbow were lower than that of the ankle suggesting that there is worse ankle joint health overall when compared to other joints. Ankle joint changes are driven by the mechanical demand on the ankle and forces exerted on the joint during activities of daily living in combination with structural and functional changes often seen in adolescents and adults with severe haemophilia [27, 28]. Our data suggest that very early signs of arthropathy might not be detected by the HJHS; rather it measures the cumulative effect of haemarthropathy, not detectable until later years.

AJBR in this study are slightly lower (Table 2) than those reported in the UK THUNDER study conducted three years earlier using the same NHD database [11]. Scott et al. reported median AJBR of 0.0 in children (0-11 years), 1.0 in adolescents (12-18 years) and 3.0 in adults aged 19 and above. Our prevalence data (Table 1) in children in adults indicate a slight decrease AJBR since the Scott et al. study [16]. In terms of the treatment profile of those included in our study, about of a quarter were now using an EHL product and $96 \%$ of those sampled are receiving and compliant with treatment. In addition Scott et al did not include those patients with haemophilia $B$ who are reported to have better joint health and less frequent joint bleeds [29]. Regardless, those sampled in this study still had up to four joint bleeds over a 12-month period, with $60 \%$ of all adults reporting a minimum of one joint bleed. Forty percent of individuals sampled reported no bleeds and were well controlled, but for the remaining $60 \%$ it is unclear why joint bleeding occurred. Understanding why the $60 \%$ in this cohort reported haemarthrosis may lead to better 
targeted and individualised treatment and identification of other contributing actors such as lifestyle and altered, combined and individual joint biomechanics of the upper and lower limbs.

A limitation of this study is the low number of patients registered on the UK database that had full Haemtrack and itemised HJHS data recorded at the time of data collection. The NHD does not report bleed level data on patients that do not use Haemtrack, limiting analysis to Haemtrack compliant users. Bias may have been introduced by the inability to include those not recording treatment in Haemtrack and those for whom HJHS examinations were not reported or itemised by joint to the NHD. Haemtrack data compliance is defined as $\geq 75 \%$ of home delivery treatment received being recorded as used by the patient; those who met the inclusion criteria are regarded as "good reporters" and deemed likely to be compliant with treatment [20]. The current profile of those who receive and record treatment, but fall below the $75 \%$ treatment adherence criteria is unknown. Understanding joint haemarthrosis in this subset of patients may provide further insight into the real-world prevalence of haemarthrosis, but presents a major challenge in data collation.

Furthermore, the sample of haemophilia B patients in this analysis is small, and therefore differences in joint bleed prevalence and HJHS between patients with haemophilia $A$ and $B$ should be interpreted with caution. Those with haemophilia B may present with a milder bleeding phenotype than that of haemophilia A regardless of severity or treatment [29-31]. In addition haemophilia B may display less severe levels of haemarthropathy, with differences in the specific pathophysiological mechanisms of joint disease underlined by different rates of joint deterioration and severity [32]. Direct comparison between disease types is limited and therefore further research is needed to explore whether the lower bleed rates and better joint health in people with haemophilia B found in this study can be confirmed.

A further limitation is between-centre variability in HJHS assessment [33]. HJHS data from different haemophilia centres may be subject to inter-centre scoring variability, although workshops have been conducted in the UK to decrease inter-centre variability in HJHS scoring. Furthermore, we are unable to confirm the influence of other factors such as the presence of co-morbid musculoskeletal conditions on HJHS data. UKHCDO NHD data was requested from those with moderate disease but there was insufficient data to include in the analysis. Future comparison by disease severity (severe and moderate) may provide further insight of those most at risk of haemarthropathy.

\section{Clinical Implication And Conclusion}

In a UK cohort of Haemtrack compliant patients with severe haemophilia without a current inhibitor, only $70 \%$ of children and $30 \%$ of adults remained haemarthrosis free during 2018 . Haemarthrosis was most likely to be reported in the knee joint in children with haemophilia $A$, the ankle joint in children with haemophilia B, the elbow and ankle joint in adults with haemophilia $A$, and the elbow joint in adults with haemophilia B. Overall higher HJHS were reported for the ankle joint compared to the knee and elbow, suggest that the ankle joint is the most severely compromised joint in people with haemophilia. 
Investigation of impact on function and potential interventions that lessen the burden of disease are warranted. Future clinical studies would also benefit from understanding the bleeding profiles of those who do not meet compliance criteria for Haemtrack to obtain the true prevalence of haemarthrosis. This report of current joint bleed prevalence and associated impact on the musculoskeletal system provides a benchmark to potentially evaluate emerging pharmacological and targeted non-pharmacological treatments.

\section{Abbreviations}

ABR: Annual bleed rate

AJBR: Annual joint bleed rate

CFC: Clotting factor concentrate

EHL: Extended half life

HJHS: Haemophilia joint health score

NHD: National Haemophilia Database

SHL: Standard half-life

UKHCDO: United Kingdom Haemophilia Doctors Organisation

\section{Declarations}

\section{Ethics approval and consent to participate}

Ethical approval was obtained to allow access the National Haemophilia Database, anonymised data. This study was approved by London Queen Square Research Ethics Committee (16/LO/2251) and NHS Health research Authority (IRAS ID 206141). Individual participant consent was not applicable.

\section{Consent for publication}

Consent to publish this paper was obtained from the UKHCDO NHD.

\section{Availability of data and materials}

The data that support the findings of this study are available from The National Haemophilia Database (NHD) but restrictions apply to the availability of these data, which were used under license for the current study, and so are not publicly available. Data are however available from the corresponding author upon reasonable request and with permission of the NHD.

\section{Competing interests}


RAW has received registration fees and support for travel from Roche.

DS has received research funding from Sobi, CSL and Roche; consultancy and speakers fees from Sobi and Takeda

EH has received speaker fees from Roche, sponsorship for travel from Sobi.

MJS has received research funding from Bayer; consultancy and speakers fees from Sobi and Roche; registration fees and support for travel from Sobi, Pfizer and CSL.

HJS is a HEE/NIHR Senior Clinical lecturer and has received funding from NIHR who also funded this research.

ACR is a NIHR Senior Investigator and has received funding from NIHR who also funded this research.

GJC, RW, HX, BP and MR report no competing interests

\section{Funding}

RAW is funded by a National Institute for Health Research (NIHR) Clinical Doctoral Research Fellowship (ICA-CDRF-2015-01-0120); ACR is in part supported through the NIHR Leeds Biomedical Research Centre, Leeds, UK. This paper presents independent research funded by the National Institute for Health Research (NIHR). The views expressed are those of the authors and not necessarily those of the NHS, the NIHR or the Department of Health.

\section{Author's contributions}

The study was conceived by RAW, AR, GC, RW and HJS. Analysis was undertaken by members of staff at the NHD (HX and BP). The manuscript was written by RAW and DS. Subsequent drafts were edited and approved by RAW, DS, MJS, AR, GC, MR, EH, HJS, and RW.

\section{Acknowledgements}

The authors would like to thank the centre directors, physiotherapists and staff of all UK haemophilia centres for their hard work in collecting data and responding to data queries. We would also like to thank the members of the UKHCDO Data Analysis Group for advising on data interpretation; Prof Charles Hay, Prof Peter Collins, Dr Elizabeth Chalmers, Dr Ryan Cheal, Prof Pratima Chowdary, Simon Fletcher, Dr Georgina Hall, Dr Dan Hart, Dr Ri Liesner, Andrew McNally, Ben Palmer, Paul Sartain, Dr Martin Scott, Dr Susie Shapiro, David Stephensen, Dr Hua Xiang. The staff at the National Haemophilia Database are also thanked for their contribution to data collection.

\section{Author's information}

\section{ORCID (those with ORCID IDs)}


Richard Wilkins: 0000-0003-1885-5472

Anthony Redmond: 0000-0002-8709-9992

Heidi Siddle: 0000-0002-6015-332X

Graham Chapman: 0000-0003-3983-6641

Martin Scott: 0000-0002-0854-1309

David Stephensen: 0000-0002-6175-3343

Rebecca Walwyn: 0000-0001-9120-1438

\section{References}

1. Bolton-Maggs, P.H. and K.J. Pasi, Haemophilias $a$ and b. The Lancet, 2003. 361(9371): p. 1801-1809.

2. Biggs, R. and R.J.B.j.o.h. Macfarlane, Haemophilia and related conditions: a survey of 187 cases. 1958. 4(1): p. 1-27.

3. Gringeri, A., B. Ewenstein, and A.J.H. Reininger, The burden of bleeding in haemophilia: is one bleed too many? Haemophilia, 2014. 20(4): p. 459-463.

4. Van Vulpen, L., K. Holstein, and C.J.H. Martinoli, Joint disease in haemophilia: Pathophysiology, pain and imaging. Haemophilia, 2018. 24: p. 44-49.

5. Roosendaal, G. and F. Lafeber, Pathogenesis of haemophilic arthropathy. Haemophilia, 2006. 12(s3): p. 117-121.

6. Hanley, J., et al., Guidelines for the management of acute joint bleeds and chronic synovitis in haemophilia. Haemophilia, 2017.

7. Manco-Johnson, M.J., et al., Prophylaxis versus episodic treatment to prevent joint disease in boys with severe hemophilia. New England Journal of Medicine, 2007. 357(6): p. 535-544.

8. Oldenburg, J., Optimal treatment strategies for hemophilia: achievements and limitations of current prophylactic regimens. Blood, 2015. 125(13): p. 2038-44.

9. Gringeri, A., et al., A randomized clinical trial of prophylaxis in children with hemophilia A (the ESPRIT Study). Journal of Thrombosis and Haemostasis, 2011. 9(4): p. 700-710.

10. Srivastava, A., et al., Guidelines for the management of hemophilia. 2013. 19(1): p. e1-e47.

11. Collins, P., et al., Efficacy and safety of secondary prophylactic vs. on-demand sucrose-formulated recombinant factor VIII treatment in adults with severe hemophilia A: results from a 13-month crossover study. Journal of Thrombosis and Haemostasis, 2010. 8(1): p. 83-89.

12. Skinner, M.W., et al., Achieving the unimaginable: Health equity in haemophilia. Haemophilia, 2019.

13. Skinner, M.W., WFH: closing the global gap-achieving optimal care. Haemophilia, 2012. 18: p. 1-12. 
14. Ebbert, P.T., et al., Emicizumab prophylaxis in patients with haemophilia A with and without inhibitors. Haemophilia, 2020. 26(1): p. 41-46.

15. Chowdary, P.J.T.R., Extended half-life recombinant products in haemophilia clinical practiceExpectations, opportunities and challenges. Thrombosis Research, 2019.

16. Scott, M.J., et al., Treatment regimens and outcomes in severe and moderate haemophilia $A$ in the UK: The THUNDER study. Haemophilia, 2019. 25(2): p. 205-212.

17. Berntorp, E., et al., European retrospective study of real-life haemophilia treatment. Haemophilia, 2017. 23(1): p. 105-114.

18. Stephensen, D., et al., Changing patterns of bleeding in patients with severe haemophilia $A$. Haemophilia, 2009. 15(6): p. 1210-1214.

19. UKHCDO. united kingdom haemophilia centre doctors organisation. 2020 [cited 2020 05/04/2020]; Available from: http://www.ukhcdo.org/nhd/.

20. Hay, C., et al., The haemtrack home therapy reporting system: Design, implementation, strengths and weaknesses: A report from UK Haemophilia Centre Doctors Organisation. Haemophilia, 2017. 23(5): p. 728-735.

21. UKHCDO, UKHCDO Annual Report 2019, including bleeding disorder statistics 2019.

22. Hilliard, P., et al., Hemophilia joint health score reliability study. Haemophilia, 2006. 12(5): p. 518-525.

23. Ribeiro, T., et al., Developing a new scoring scheme for the Hemophilia Joint Health Score 2.1. Research and practice in thrombosis and haemostasis, 2019. 3(3): p. 405-411.

24. Hakobyan, N., et al., Pathobiology of hemophilic synovitis l: overexpression of mdm2 oncogene. Blood, 2004. 104(7): p. 2060-2064.

25. Roosendaal, G., et al., Blood-induced joint damage: a canine in vivo study. Haemophilia, 1999. 42(5): p. 1033-1039.

26. Hooiveld, M., et al., Blood-induced joint damage: longterm effects in vitro and in vivo. The Journal of rhematology, 2003. 30(2): p. 339-344.

27. Pasta, G., et al., Orthopaedic management of haemophilia arthropathy of the ankle. Haemophilia, 2008. 14(s3): p. 170-176.

28. Rodriguez-Merchan, E.C., Management of hemophilic arthropathy of the ankle. Cardiovascular and Hematological Disorders - Drug Targets, 2017. 17(2): p. 111-118.

29. Mannucci, P. and M.J.H. Franchini, Is haemophilia B less severe than haemophilia A? Haemophilia, 2013. 19(4): p. 499-502.

30. Santagostino, E., et al., Severe hemophilia with mild bleeding phenotype: molecular characterization and global coagulation profile. Journal of Thrombosis and Haemostasis

31. 8(4): p. 737-743.

32. Castaman, G. and D.J.h. Matino, Hemophilia A and B: molecular and clinical characteristics of similar, but different diseases. Haematologica 2019: p. haematol. 2019.221093. 
33. Melchiorre, D., et al., Clinical, instrumental, serological and histological findings suggest that hemophilia B may be less severe than hemophilia A. Haematologica, 2016. 101(2): p. 219-225.

34. Nijdam, A., et al., Using routine Haemophilia Joint Health Score for international comparisons of haemophilia outcome: standardization is needed. Haemophilia 2016. 22(1): p. 142-147.

\section{Figures}

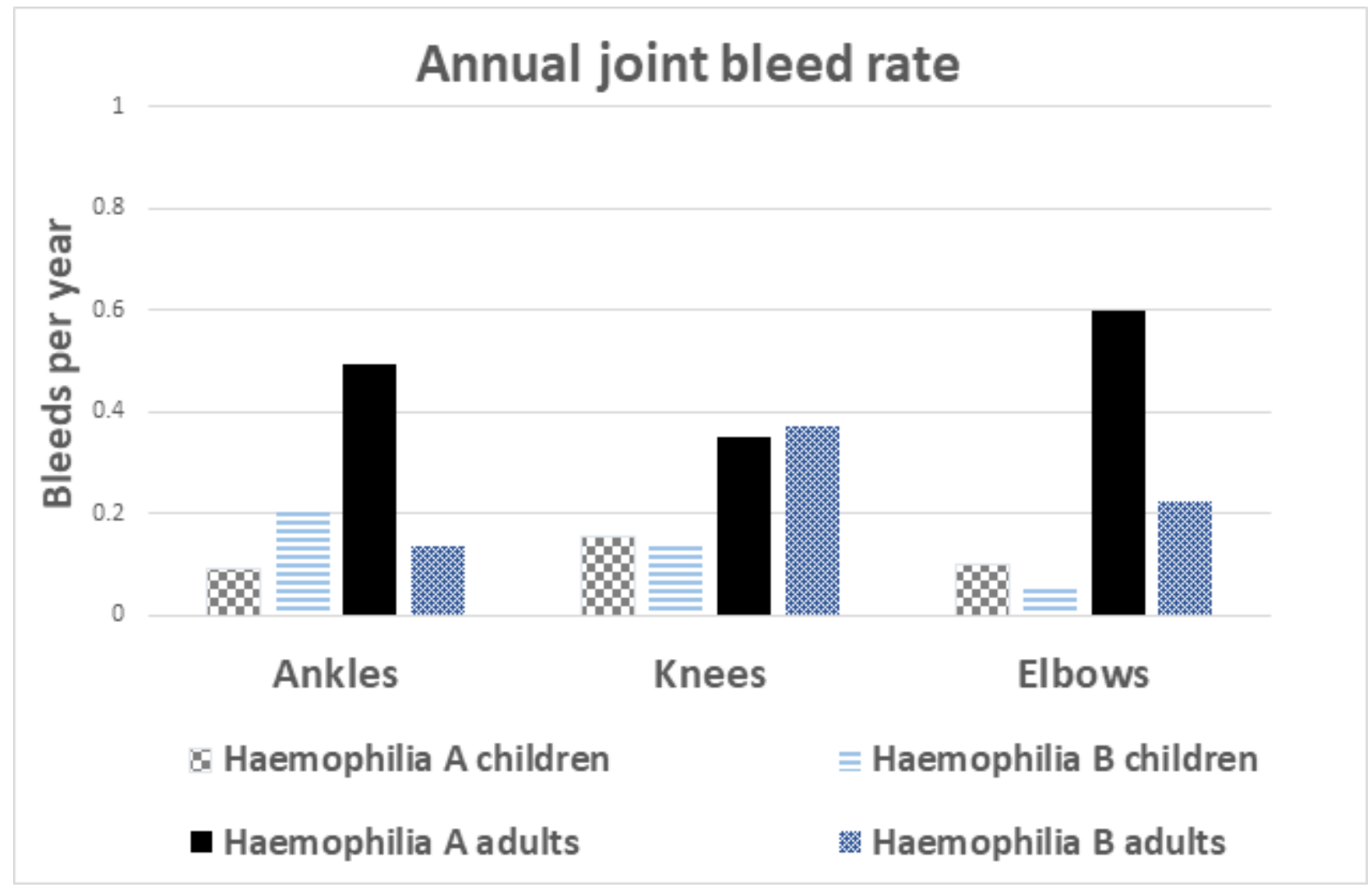

\section{Figure 1}

Combined AJBR for children and adults with severe haemophilia A and B. 


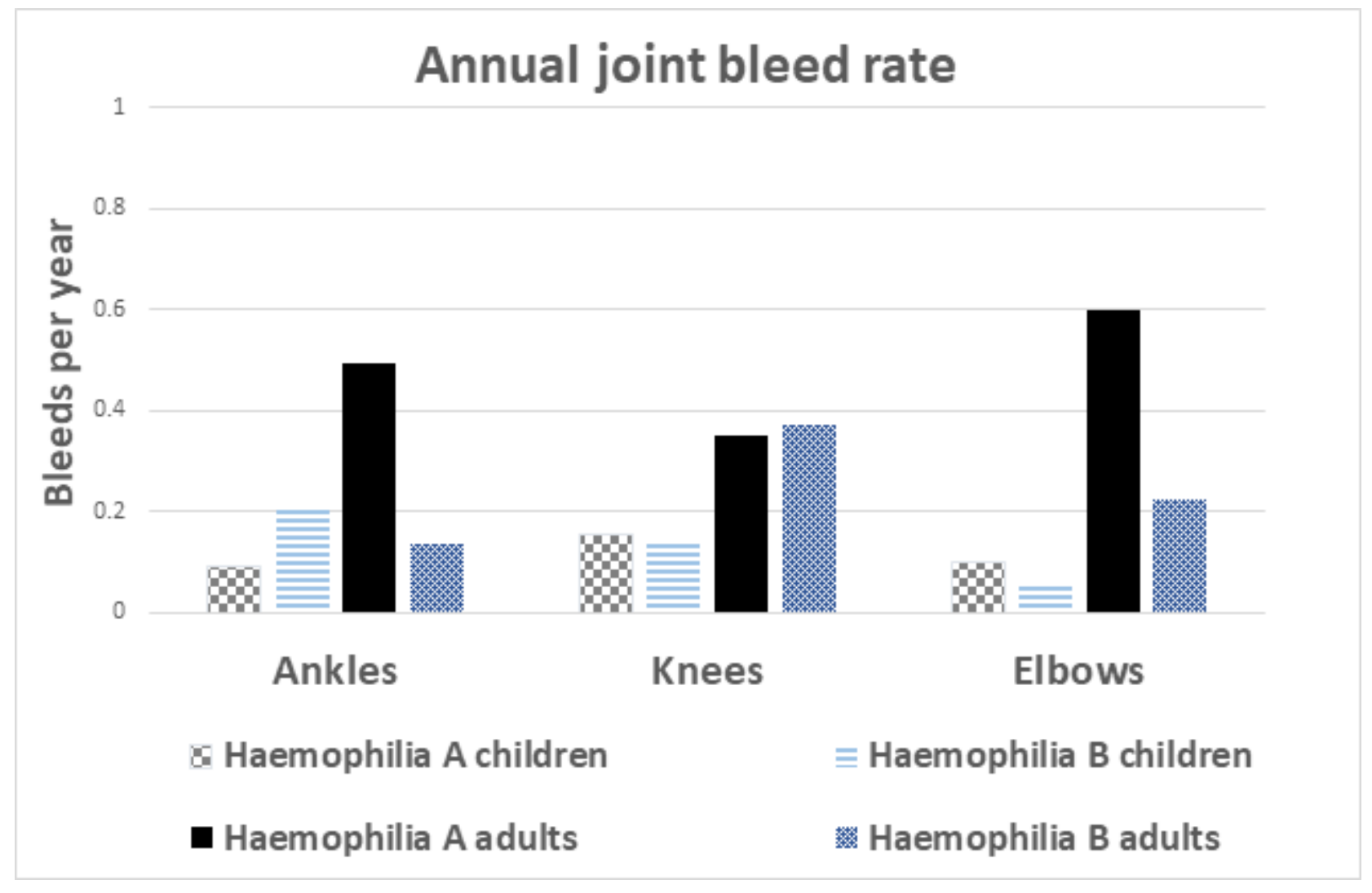

Figure 1

Combined AJBR for children and adults with severe haemophilia A and B. 